Review Article

\title{
COELENTERATE TOXINS, ITS PHARMACEUTICAL AND THERAPEUTIC EFFECTS
}

\author{
SIMRAN SHARMA, RAVI KANT UPADHYAY \\ Department of Zoology, Deen Dayal Upadhyaya Gorakhpur University, Gorakhpur \\ Email: rkupadhya@yahoo.com
}

Received: 04 Aug 2021, Revised and Accepted: 10 Oct 2021

\begin{abstract}
Present review article emphasizes species specific coelenterate toxins, its pharmaceutical and therapeutic effects. Most of the coelenterates inflict venom accidently by using nematocysts found on arms. These animals very quickly do massive and multiple inflictions of venom which causes cardiotoxicity that leads to the death of human beings. Coelenterate venom toxin groups differ in their composition and show diverse biological activity i.e. cytolytic or neurotoxic, hemolytic, anti-parasitic activity, $\alpha$-amylase inhibitor activity, and analgesic activity anti-cancerous and antitumor activity, anti-inflammatory and antimicrobial activity. Coelenterate venom initiates toxic and immunological reactions exert their effects by modifying the properties of the ion channels involved in action potential generation in nerve, heart, and skeletal muscles. This article suggests available information, on coelenterate toxins could be used to develop potential therapeutic interventions for various human diseases and disorders.
\end{abstract}

Keywords: Coelenterate toxins, Ion channels, Venoms biological, Pharmaceutical and therapeutic effects

(C) 2021 The Authors. Published by Innovare Academic Sciences Pvt Ltd. This is an open access article under the CC BY license (https://creativecommons.org/licenses/by/4.0/)

DOI: https://dx.doi.org/10.22159/ijcpr.2021v13i6.1912 Journal homepage: https://innovareacademics.in/journals/index.php/ijcpr

\section{INTRODUCTION}

Coelenterate venom toxins were evolved during very long evolutionary period. The origin of venom shows biological relevance as it was evolved in response to predator attack and for feeding to immobilize or kill the prey. In coelenterates defense organs were evolved due to environmental adaptations and survival competition during long evolutionary selection and mutational mechanisms. Both production of venom, its infliction, intelligence, and genetic coherence seems integration of genetic system and environmental change [1]. Coelenterates have been divided in five main classes of toxic marine animals: Anthozoa, Cubozoa, Scyphozoa and Hydrozoa. They are the largest and oldest phylum of toxic marine animals which use venom for their territorial protection from enemies and hunting the prey [2]. Coelenterates use toxins for prey acquisition, and to deter potential predators (with neurotoxicity and cardiotoxicity effects) and to fight territorial disputes (table 1).

Cnidarians are the oldest extant lineage of venomous animals on earth. The Anthozoa class includes sea anemones, hard corals, soft corals and sea pens. Anthozoan orders Alcyonacea and Gorgonacea exhibit by far the highest number of species yielding promising compounds [3]. Cnidrians are highly sensitive climate change i.e. corals and anemones have undergone climate-induced bleaching due to present extreme environmental conditions. Climate has largely affected the symbiotic relationships in sea anemones and photosynthetic algae (zooxanthellae) are showing whitening of their color (table 1). These environmental changes are also responsible for loss of internal food supply and reduction in health that results in the death of coelenterates [4].

\section{Organs of defense}

Cnidarians have also developed venomous apparatus nematocysts for the injection of toxins into the victim. The nematocyst is one of the most complex intracellular structures found cnidarians (sea anemones, corals, jellyfish, and hydroids) (fig. 1). This battery-like structure helps to inject the venom that initiates toxic and immunological reactions in the envenomated organism. Most cnidarian members attack/defend very fast and efficiently and cause massive envenomation in humans that result in death. Nematocyst discharge in coelenterates is related to the toxins found in cell-and tubule-walls of nematocysts including their polysialic acid (polySia) dependent target function. The nematocyst of the sea anemone Nematostella vectensis contain contains putative venom proteins, a metallopeptidase found in pharyngeal gland cells [5]. Venom infliction affects survival, functioning and metabolism in coelenterates animals (table 1). The nematocyst discharge process can be used in the development of nanomedical devices for cancer diagnostics and therapies [6] (table 1).

\section{Venom composition}

Cnideriantoxins comprises of large variety of polypeptide and protein toxins which contain proteinaceousandnon-proteinaceous compounds (purines, quaternary ammonium compounds, biogenic amines and betaines). Cniderian venom is rich source of peptides i.e. phopholipase A2, (EGF)-like toxin (gigantoxin I), Shk, APETx2 [7] (table 1). Most of the peptides are typically 10-60 amino acids long, and folded into well-defined secondary structures. Few of these peptides are enzymatic in nature and are major inhibitors or modulators of different ion channels and neurotransmitter receptors with high potency and selectivity. These are stabilized by multiple, highly-conserved disulfide bonds and are cysteinestabilized toxins which exert their effects by modifying the properties of the ion channels involved in action potential generation in nerve, heart, and skeletal muscle. Sea anemone venom toxins posses three receptor sites Type I and Type III sodium channel inhibitors Phospolipase acts as Type I and Type III sodium inhibitors of both sodium and potassium voltage-gated channels [8] (table 1) (fig. 1).

Cnidarian toxins comprise a large variety of polypeptide and protein toxins (e. g. most toxins from sea anemones and jellyfish) as well as other organic compounds. Currently, around 250 of those compounds have been identified. Only few proteins have been deduced for their three-dimensional structures. The diversity of the chemical structure of these compounds is also reflected in a great variety of their action on cells and imposes path physiological effects suchcardiotonic, cardiotoxic, neurotoxic in man [9].

\section{Cnidarians toxins}

\section{Sea anemones toxins}

Sea anemone (Cnidaria, Anthozoa) venom is an important source of bioactive compounds, mainly toxins. These cause severe cardiotoxicity and results in the death of human beings [10]. Tube anemones or cerianthids, posses venom in stinging-cell rich tentacles prey and defend against predators [11]. These animals 
produce venoms of exceptional molecular diversity. These venom components also show diverse pharmacological activity and amino acid sequence [12]. Sea anemones possess APETx1 and APETx2 toxin peptides, first one inhibits human potassium channels, while second one inhibits acid-sensing ion channels in sensory neurons. Gigantoxin I also acts as an epidermal growth factor (EGF)-like toxin
[13]. From Sea anemones possess four different types of channels i.e. type 1 toxins to inhibit Shaker-related $K_{V}$ channel currents by a "functional dyad" directly interacting with the channel pore. Similarly, $\alpha$-actitoxin-Ate1a (Ate1a) selectively inhibits voltagegated potassium channel [14]. BDS-I and II, selectively which target Kv3.4 channels (table 2) (fig. 1).

Table 1: Showing major coelenterate venoms with their major physiological effects

\begin{tabular}{|c|c|c|c|c|}
\hline S. No. & Species name & Toxins & Effects & References \\
\hline 1. & Chrysaorafuscescens & $\begin{array}{l}\text { Proteinases, venom allergens, C- } \\
\text { type lectins, pore-forming toxins, } \\
\text { glycoside hydrolases }\end{array}$ & $\begin{array}{l}\text { Ion channel blockade and } \\
\text { modulatory activities }\end{array}$ & Ponce D et al. 2016 \\
\hline 2. & Stichodactyla helianthus & ShK & Potassium channel blocker & J. Prentis P et al. 2018. \\
\hline 3. & Protopalythoa variabilis & ShK/Aurelin family & $\begin{array}{l}\text { Neurotoxic peptides, hemostatic and } \\
\text { hemorrhagic toxins, pore-forming } \\
\text { proteins, }\end{array}$ & Huang C et al. 2016. \\
\hline 4. & Anthopleura elegantissimanot & Actinoporins & Protease inhibitors & $\begin{array}{l}\text { Tomohiro Honma et al. } \\
2005 .\end{array}$ \\
\hline 5. & Eisenia foetida & Lysenin & Pore-forming toxin & Sukumwang N et al. 2013. \\
\hline 6. & Palythoa caribaeorum & PcShK3 & Neuro-and cardio-protective & Liao Qet al. 2018. \\
\hline 7. & Hydra magnipapillata & Actinoporins & Haemolytic activity & Liew YJM et al. 2015. \\
\hline 8. & Heteractis crispa & APETx2 & Acid-sensing ion channels & Kalina RS et al. 2020. \\
\hline 9. & Bunodosomacaissarum & BcsTx1 and BcsTx2 & Potassium channel toxins & Diego J. B. Orts, et al. 2013 \\
\hline 10. & Phymanthus crucifer & PhcrTx1 & $\begin{array}{l}\text { An acid-sensing ion channel (ASIC) } \\
\text { inhibitor }\end{array}$ & $\begin{array}{l}\text { Armando Alexei Rodríguez, } \\
\text { et al. } 2018 .\end{array}$ \\
\hline
\end{tabular}

Table 2: Showing major sea anemone venoms with their major physiological effects

\begin{tabular}{|c|c|c|c|c|}
\hline S. No. & Species name & Peptide toxins & Biological effects & References \\
\hline 1. & Actinia equina & Ae I & Sodium channel toxins & Lin et al., 1996 \\
\hline 2. & Anemonia erythraea & AETX I & Cardiac channel & Shiomi et al., 1997 \\
\hline 3. & Anemonia sulcata & ATX Ia and Ib & sodium channel toxins & Widmer et al., 1988 \\
\hline 4. & Anthopleura elegantissima & ApC & Voltage-gated sodium channels & Norton, 1981 \\
\hline 5. & Anthopleura fuscoviridis & AFT I and II & neurotoxins acting on voltage-gated sodium channels & Sunahara et al., 1987 \\
\hline 6. & Anthopleura xanthogrammica & ApA & Cardiac channel & Tanaka et al., 1977 \\
\hline 7. & Anthopleura sp. & $\begin{array}{l}\text { Hk2a, 7a, 8a, and } \\
16 a\end{array}$ & Cardiac channel & Wang et al., 2004 \\
\hline 8. & Bunodosoma caissarum & Bc III & neurotoxins acting on voltage-gated sodium channels & Malpezzi et al., 1993 \\
\hline 9. & Bunodosoma cangicum & Cangitoxin & neuronal sodium channels & Cunha et al., 2005 \\
\hline 10. & Bunodosoma granulifera & Bg II and III & $\begin{array}{l}\text { 3-to } 5 \text {-kDa neurotoxins acting on voltage-gated } \\
\text { sodium channels }\end{array}$ & Loret et al., 1994 \\
\hline 11. & Condylactispassiflora & Cp I and II & voltage-gated sodium channels & Shiomi et al., 1995 \\
\hline 12. & Stichodactyla helianthus & Gigantoxin II & Cardiac channel & Shiomi et al., 2003 \\
\hline 13. & Stichodactylagigantea & Gigantoxin II & $\begin{array}{l}\text { 3-to } 5 \text {-kDa neurotoxins acting on voltage-gated } \\
\text { sodium channels }\end{array}$ & Kem et al., 1989 \\
\hline 14. & $\begin{array}{l}\text { Radianthus (Heteractis) } \\
\text { paumotensis }\end{array}$ & Rc I & voltage-gated sodium channels & Shiomi et al., 1996 \\
\hline 15. & Antheopsismaculata & Am III & voltage-gated sodium channels & Honma et al., 2005 \\
\hline
\end{tabular}

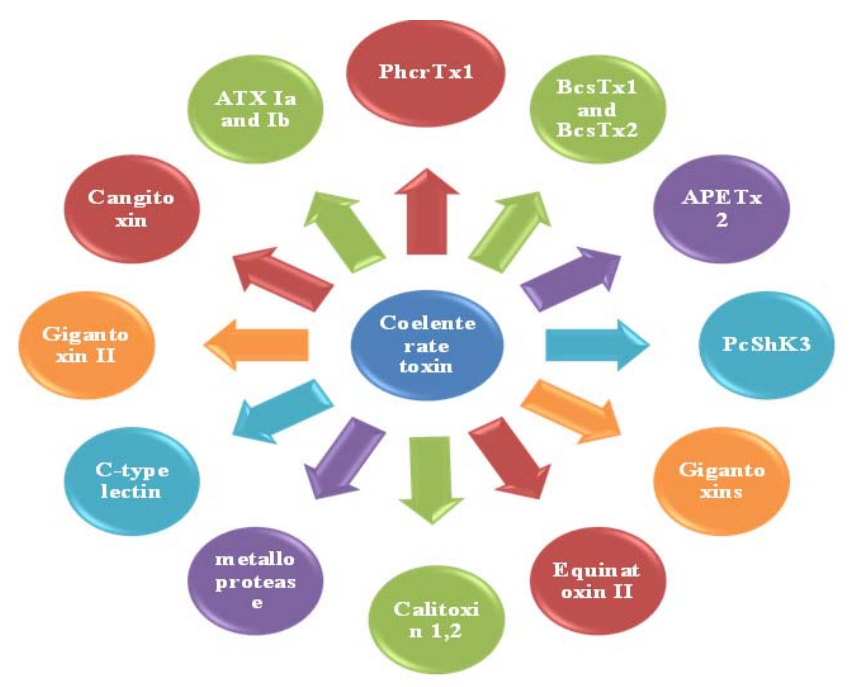

Fig. 1: Coelenterate venom toxin molecules isolated from different species 
PhcrTx1 toxin characterized from the sea anemone Phymanthus crucifer, is ASIC inhibitor shows lower potency on Kv channels [15]. Sea anemone Anthopleura dowii Verrill venom contains a neurotoxins, including proteases, that act as either potassium $\left(\mathrm{K}^{+}\right)$or sodium $\left(\mathrm{Na}^{+}\right)$channels inhibitors [16]. These neurotoxins act upon a diverse panel of ion channels, such as voltage-gated sodium and potassium channels. These mainly target sodium channels and are modifiers of these channels [17]. These toxins target Voltage-gated $\mathrm{Na}(+)$ channels and are responsible for the conduction of electrical impulses in sea anemone, consist of cysteine-rich peptides capable of binding different extracellular sites of this channel protein. Four different types of neurotoxins with different structure and mode of action have been isolated from sea anemones [18] (table 2).

Sea anemone type 1 peptides known found active on $\mathrm{Na}(\mathrm{v}) 1 \mathrm{x}$ channels. These peptides are 46-49 amino acid residues long contain three disulfide bonds and their molecular weights range between 3-5 Kda [19]. Sea anemone Anthopleura maculate contain three peptide toxins (Am I-III) with crab toxicity Type 1 sea anemone sodium channel toxins, both Am I (27 residues) and II (46 residues) are potent neurotoxins [20]. Sea anemone Heteractis crispa contain neurotoxin RTX-VI that modulates the voltage-gated sodium channels ( $\mathrm{Nav}$ ). The
RTX-VI molecule consists of two disulfide-linked peptide chains and is devoid of Arg13, for the Nav channels. System (Nav1.2, Nav1.6) and insect (BgNav1, VdNav1) sodium channels [21]. A neurotoxin (BDS)like antimicrobial peptides (AMPs)-Crassicorin-I and its putative homolog (Crassicorin-II) that was isolated from the pharynx extract of an anthozoan sea anemone (Urticina crassicornis). Crassicorin-I shows the functional linkage between AMPs and neurotoxins in a basally branching metazoan [22] (table 2).

The sea anemone Stichodactyla haddoni contains peptide toxins, SHTX I-III with crab-paralyzing activity, an epidermal growth factorlike peptide and SHTX IV with crab lethality. SHTX I (new toxin, 28 residues), II (analogue of SHTX I, 28 residues) and III (Kunitz-type protease inhibitor, 62 residues) are potassium channel toxins and SHTX IV (48 residues) is a member of the type 2 sea anemone sodium channel toxins [20]. Indeed, cnidarians are considered is largest phylum of toxic animals. These toxic products, particularly peptide toxins, could be used as a promising target for biomedicine research. Stichodactyla helianthus contains potassium channel blocker ShK its analogue ShK-186 for the treatment of autoimmune diseases [23] (table 2) (fig. 2).

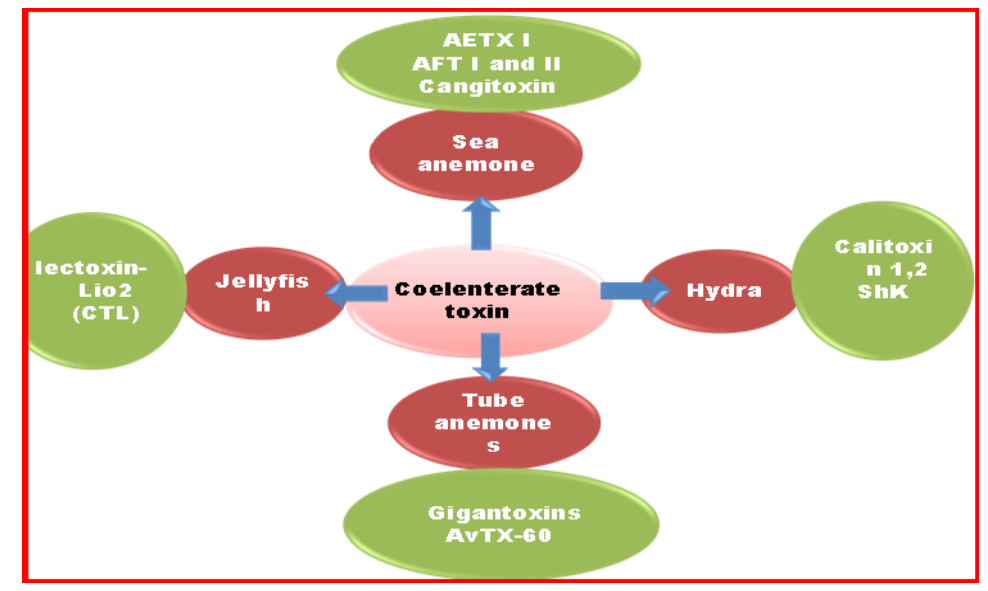

Fig. 2: Major venom toxins isolated from hydra, jelly fish, sea anemone toxins and tube anemones

Table 3: Showing major various venom toxins with their major biological effects

\begin{tabular}{|c|c|c|c|c|}
\hline S. No. & Toxin type & Peptide toxins & Biological effects & References \\
\hline 1. & Neurotoxins & ATX-II & Slows NaC inactivation & D. Sher et al., 2005 \\
\hline 2. & Neurotoxins & ATX-III & Slows $\mathrm{NaC}$ inactivation & D. Sher et al.,2005 \\
\hline 3. & Neurotoxins & Calitoxin 1,2 & $\begin{array}{l}\text { Release of neurotransmitter, possibly affecting } \\
\mathrm{NaC} \text { channels }\end{array}$ & D. Sher et al.,2005 \\
\hline 4. & Neurotoxins & BDS-I,II & Blocks fast inactivating KC channel Kv 3.4 & D. Sher et al.,2005 \\
\hline 5. & Neurotoxins & ShK & $\begin{array}{l}\text { Blocks voltage dependent KC channels Kv1.3 } \\
\text { and 1.1. Isolated from homogenized bodies }\end{array}$ & D. Sher et al.,2005 \\
\hline 6. & Neurotoxins & AeK & Block voltage gated $\mathrm{KC}$ channels & D. Sher et al.,2005 \\
\hline 7. & Neurotoxins & APETx1,2 & Blocks ether-a-go-go KC channels & D. Sher et al.,2005 \\
\hline 8. & Cytolysins & Equinatoxin II & $20 \mathrm{kDa}$, pore-former, toxic & D. Sher et al.,2005 \\
\hline 9. & Cytolysins & CaTX-A & $43 \mathrm{kDa}$, pore-former, toxic & D. Sher et al.,2005 \\
\hline 10. & Cytolysins & AvTX-60 & $60 \mathrm{kDa}$, pore-former, toxic, MAC-PF domain & D. Sher et al.,2005 \\
\hline 11. & Cytolysins & Hln & $27 \mathrm{kDa}$, pore-former, toxic & D. Sher et al.,2005 \\
\hline 12. & Phospholipases & Jellyfish Phospholipase A2 & neurotoxic activity & D. Sher et al.,2005 \\
\hline 13. & EGF-like toxins & Gigantoxins & $\begin{array}{l}\text { 3-to } 5 \text {-kDa neurotoxins acting on voltage-gated } \\
\text { sodium channels }\end{array}$ & D. Sher et al.,2005 \\
\hline
\end{tabular}

\section{Jellyfish toxins}

Jellyfish are scyphozoans which possess venoms which is rich sources of toxin petides and protein. Jellyfish use stings to capture prey or deter predators. These are a major threat to human beings in coastal areas. Jellyfish Stomolophusm eleagris is a very dangerous animal because of its strong toxicity. The mesoglea of a scyphoid jellyfish Aurelia aurita contain 40-residue antimicrobial peptide, aurelin. Each year, hundreds of thousands of victims are stung by venomous jellyfish. Nemopilema nomurai phospholipases causes highly lethality after stinging. These toxins mainly cell membraneand show thrombin-like activity and cause hemolysis [24]. Preproaurelin is a 84-residue signal peptide that have 22 amino acids. This peptide shows partial similarity with defensins and $\mathrm{K}+$ channel-blocking toxins of sea anemones which belongs to ShKT domain family [25] (table 3). 
The major components in toxins are C-type lectin, phospholipase $A_{2}$, potassium channel inhibitor, protease inhibitor, metalloprotease, hemolysin and other toxins. Presence of the compounds make sting more toxic [26] Jellyfish envenomations shows dermatological symptoms, and cause inflammation. This venom induced inflammation may be caused due inhibitory effects of matrix metalloproteinase (MMP) inhibitors for venom-induced inflammation were explored at a cellular level [27] (table 3).

\section{Protopalythoa}

Protopalythoa is a zoanthid together with marine species hydra, jellyfish, and sea anemones, composes the oldest eumetazoan phylum, i.e., the Cnidaria. These animals are highly venomous organisms that can produce deadly toxins for preying, or for territorial for defense. Zoanthid Protopalythoa variabilis, contain venomputative proteins from different toxin families. Most of them are neurotoxic peptides, hemostatic and hemorrhagic toxins, membrane-active (pore-forming) proteins, protease inhibitors, mixed-function venom enzymes, and auxiliary venom proteins. These toxins products belongs to ShK/Aurelin family and anthozoan toxin present in larval zebrafish [28].

\section{Hydra toxins}

Hydra is one of the evolutionary oldest animals with naturally occurring tumors. It forms a causal relationship between an environmental spirochete (Turneriella spec.) [29]. Similar hydra metalloproteinase, HMP1, and odocoryne metalloproteinase 1 (PMP1) have been also isolated from jellyfish and sea anemone toxins [30] (table 3).

\begin{abstract}
Allomones
Cnidarians possessallomonal system that consists of various toxin types' neurotoxins, cytolysins and toxic phospholipapses. Mainly allomones are secreted from specialized stinging cells or nematocytes found either on arms or in other body tissues. These are used to make a defense against predators and prey capture for feeding. Feeding behavior in Hydra is maintained by receptors to GABA and glycine in the neuromuscular circuitry [31]. Hydrae also possess proteins similar to elapid-like phospholipases, CRISP proteins, Prokineticin-like polypeptides and toxic deoxyribonucleases [32]. These also possess neuropeptides in neurons of the basal disk, gastric region and tentacles [33]. Cnidarian, Hydra vulgaris contains newastacin proteinase, a hydra metalloproteinase 2 (HMP2). The mature HMP2 contains 496 amino acids and a zinc-binding motif. It shows resemblance to meprins, a subgroup of astacin metalloproteinases characteristic of the astacin family. Hydra nematocysts secrete minicollagen-1 which is a trimeric protein having cysteine-rich domains at the $\mathrm{N}$ and $\mathrm{C}$ termini [34] (fig. 2).
\end{abstract}

\section{Toxin peptides from coelenterates}

\section{Cytolysins}

Cytolysins, toxins found in sea anemone with Kunitz-type protease inhibitors activity and toxins with Phospholipase A2 activity [35] (fig. 2).

\section{ShK}

Sea anemone Stichodactyla helianthus possess ShK toxin a 35 residue peptide that is a potent blocker of potassium channels i.e. $\mathrm{K}_{\mathrm{v}} 1.3, \mathrm{~K}_{\mathrm{v}}$ subtypes, such as the $\mathrm{K}_{\mathrm{v}} 1.1$, and $\mathrm{K}_{\mathrm{v}} 3.2$ channels [36] (fig. 2).

\section{ShK-like2}

The sea anemone Nematostella vectensis contain ShK-like1 peptide which has a ShKT cysteine motif. This peptide is lethal for fish larvae and packaged into nematocysts. ShK-like1 is a toxic venom component. Its paralog, ShK-like2, is a neuropeptide localized to neurons. Both peptides show similarities in their functional activities [37] (fig. 2).

\section{PcShK3}

Zoantharian PcShK3 peptide shows cardio-protective and neuroprotective activity. It contains the canonical ShK domain in its structure. Several ShK analogs or valuable variants are also characterized which are of high therapeutic value [38] (fig. 2).

\section{APETx2}

Sea anemone Anthopleura elegantissima contains APETx2, a peptide toxin effector of ASIC3. It contains 42-amino-acid peptide crosslinked by three disulfide bridges. APETx 2 causes pain and associated to acid-sensing ion channels (ASIC) are proton-gated sodium channels [39] (Acid-sensing ion channel 3 (ASIC3) inhibitors revealed ASIC3-sustained currents' inhibition for promotion of acidosis-related pain relief [40] (fig. 2).

\section{BcsTx1 and BcsTx2}

Bunodosoma caissarum contain toxinsBcsTx1 and BcsTx2 from Saint Peter and Saint Paul Archipelago, Brazil. Sequence alignment and phylogenetic analysis shows that BcsTx1 and BcsTx2 are the newest members of the sea anemone type 1 potassium channel toxins [41] (fig. 2).

\section{PhcrTx1}

Sea anemone Phymanthus crucifer containPhcrTx1, a peptide toxin ASIC inhibitor. Acid-sensing ion channels (ASICs) are H+-gated $\mathrm{Na}+$ channels that belongs toENaC/degenerin superfamily of sodium channels. ASICs possess numerous functions such as sensory perception, synaptic plasticity, learning, memory formation, cell migration and proliferation, nociception, and neurodegenerative disorders [42] (fig. 2).

\section{Nematogalectins}

Nematogalectins are bridging proteins found in tubule cell walls of nematocysts in jellyfish and hydra. These are used for nematocyst discharge process. During the nematocyst discharge process, two properties takes place pressure threshold and elasticity which is beneficial with an impact on the construction of new nanomedical devices $[43,45]$ (table 4) (fig. 2).

Table 4: Showing major Jellyfish toxins venoms with their major biological effects

\begin{tabular}{|c|c|c|c|c|}
\hline S. No. & Species name & Peptide toxins & Biological effects & References \\
\hline 1. & R. esculentum & C-type lectin lectoxin-Lio2 (CTL) & Hemostasis-impairing toxins & Gacesa, R. et al. 2016 \\
\hline 2. & S. malayensis & Snaclecbothrojaracin subunit beta (BJC subunit beta) & Hemostasis-impairing toxins & Gacesa, R. et al. 2016 \\
\hline 3. & C. capillata & metalloprotease & protease-mediated tissue damage & Wang, C. et al. 2019 \\
\hline 4. & Chironex fleckeri & metalloprotease & protease-mediated tissue damage & Brinkman et al. 2011 \\
\hline
\end{tabular}

\section{Sticholysins}

Sticholysins are the actinoporins produced by Stichodactyla helianthus. Three different isotoxins are known: Sticholysins I, II, and III. More especially, sticholysinsinteract with biological membranes and display lytic activity and ability to interact with cholesterol, an important lipid component of vertebrate membranes [44] (fig. 2).

\section{Actinoporins}

Actinoporins are small $18.5 \mathrm{kDa}$ pore-forming toxins isolated from H. crispa and Heteractis magnifica. HALT-1 and other actinoporins have similar mechanisms of pore formation. Hydra magnipapillata, contain six actinoporin and HALT-1 (Hydra actinoporin-like toxin-1) shows haemolytic activity [45] (table 3). These proteins form pores in biological membranes and can work as therapeutic agents for cancer therapy.

\section{Cytolytic or neurotoxic}

\section{Biological effects}

Cnidarians possess nematocysts found on their tentacles, acrorhagi and acontia, and in the mucous coat that covers the animal body. Sea 
anemone possesses proteins and peptides which showcytolytic or neurotoxic activity. Potency of these toxins potency varies with the structure and site of action. These different target animals, such as insects, crustaceans and vertebrates. Sea anemones toxins include voltage-gated $\mathrm{Na}^{+}$and $\mathrm{K}^{+}$channels toxins, acid-sensing ion channel toxins, Cytolysins, toxins with Kunitz-type protease inhibitors activity and toxins with Phospholipase A2 activity. Similarly, Palythoa caribaeorum venom toxins show cytolytic activity against U251 and SKLU-1 cancer cell lines [46] Cnidarian venoms shows cytotoxic and hemolytic effects (fig. 3 ).

\section{Hemolytic activity}

Sea anemone Entacmaea quadricolor contain venom toxins in nematocysts that show haemolytic effects. The A. equina mucus matrix shows hemolytic activity on rabbit erythrocytes, cytotoxic activity against the tumor cell line K562 (human erythromyeloblastoid leukemia) and antibacterial lysozyme-like activity [47] H. crispa contain actinoporins which show potential hemolytic activity, it is employed as an offensive and defensive chemicals by corals as an armament [34]. Actinoporin show consistent different hemolytic activity in all representatives of their group (Elena Leychenko, et al. 2018. Sea anemones H. crispa is an apore-forming toxin belongs to actinoporins that show hemolytic activity of [48]. Stylophorapistillata $\alpha$-Pocilopotoxin-Spi1 toxin $(\alpha-$ PCTX-Spi1) also shows hemolytic activity (fig. 3).

\section{Anti-parasitic activity}

Sea-anemone Stichodactyla helianthus contain cholysin I and II from (St I and St II) and Actinia equina (EqtII) contain equinatoxin II. Seaanemone also contain cytolysins which have Kunitz-type protease inhibitors activity. These toxins efficiently kill Giardia cells and show anti-parasite specificity with anti-Giardia antibodies [49] (fig. 3).

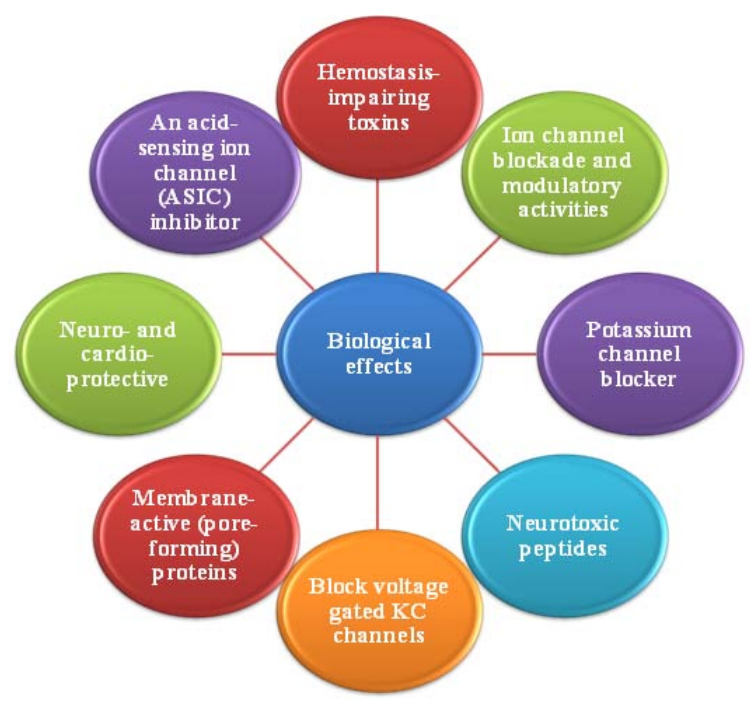

Fig. 3: Coelenterate venom toxins and its various biological activities

\begin{abstract}
Antimicrobial activity
Sea anemone $B$. verrucosa contain the putative toxin, mainly metalloproteinases and neurotoxins. These also showed antimicrobial effects. Hydramacin-1 is a toxin isolated from Hydra possesses antimicrobial activity. Hydramacin-1 is potently active against Gram-positive and Gram-negative bacteria, including multiresistant human pathogenic strains. Mason B, et al. 2021. Arminin 1a-C is also an antimicrobial peptide (AMP) is also isolated from metazoan marine Hydra [50].
\end{abstract}

\section{$\alpha$-amylase inhibitor activity}

Sea anemone Heteractismagnifica contain magnificamide a44 amino acid peptide $(4.77 \mathrm{kDa}) \mathrm{Da})$. It shows major $\alpha$-amylase inhibitory activity on cytoplasmic membranes and ion channels. More especially, pancreatic $\alpha$-amylase inhibitors that controls the glucose level in the blood and is highly useful in type 2 diabetes mellitus [51].

\section{Analgesic activity}

Sea anemone Urticinagrebelnyi contain Ugr 9-129 amino acid peptides cross-linked by two disulfide bridges shows analgesic activity [52] Ueq 12-1 is a unique peptide potentiator of the TRPA1 receptor. This is isolated from Urticinaeques that produces analgesic activity [53]. The cold-water sea anemone Cnidopus japonicas contain neurotoxins, toxin-like molecules, linear polypeptides (Cys-free), enzymes, which show analgesic effects [60] Sea anemone contains one bioactive peptide named $\alpha$-AnmTxUeq 12-1 (Ueq 12-1) (fig. 3).

\section{Anti-cancerous activity}

Cnidarians possess venom toxins which show cytotoxic, hemolytic and anti-tumour effects [8, 54]. Palythoacari baeorum venom contains compounds which show ant-cancer activity [46]
(FernandoLazcano-Pérez et al. 2018. Palythoacaribaeorum possess $\mathrm{PLA}_{2}$ activity that showspecific cytotoxicity against U251 and SKLU1 cancer cell lines. Actinoporins constitute a unique class of poreforming toxins found in sea anemones that are able to bind and oligomerize in membrane. These cause cell swelling, impairment of ionic gradients and cell death. Sticholysins I and II (Sts, StI/II), areactinoporins that interact with biological membranes of cells and form pores. Sticholysins I and II also show anti-tumor effects Carlos [55]. Sea anemone Anemonia viridis show cytotoxic andantiproliferative activities on cancer cell lines [56]. Pelagianoctiluca $(P$. noctiluca) venom shows anticancer and nitric Oxide (NO) inhibition activities. It also showed anti-proliferative activity on several cell lines, such as human bladder carcinoma (RT112), human glioblastoma (U87), and human myelogenous leukemia (K562). $P$. noctiluca venom toxins do natural inhibition of cancer cell lines [66]Sea anemones Anemonia viridis, contain Kunitz-type inhibitor, interact with cell membrane and bind to integrin due presence of an Arginine Glycin Aspartate (RGD) motif. This inhibitor stops new blood vessel growth or anti-angiogenesis effects [57]. Activities and Prevents HT-29 Colorectal Cancer Cell Migration [58] (fig. 3).

Nemopilema nomurai jellyfish venom (NnV) has anticancer activity. $\mathrm{NnV}$ strongly induced cytotoxicity of HepG2 cells through apoptotic cell death NnV inhibited the phosphorylation of PI3K, PDK1, Akt, mTOR, p70S6K, and 4EBP1, NnV exerts highly selective cytotoxicity in HepG2 cells via dual inhibition of the Akt and mTOR signaling pathways, but not in normal cells [59] (fig. 3).

\section{Anti-angiogenesis}

Sea Anemone Anemonia viridis contains a low molecular weight protein that shows anti-Angiogenic Activity. It also limits the proliferation of endothelial cells proliferation and angiogenesis. It 
shows trypsin activity inhibition of a Kunitz-type inhibitor that interact with an integrin due to an Arginine Glycin Aspartate (RGD) motif [60]. The anti-angiotensin I converting enzyme activity of box jellyfish, Chiropsalmus quadrigatus Haeckel contanvenom hydrolysate. Angiotensin I converting enzyme (ACE) shows inhibitory activity [61] (fig. 3).

\section{Antioxidant activities}

The jellyfish Rhizostoma pulmo undergoes possess collagen peptides have significantly higher AA and possess greater protective effect against oxidative stress in HEKa than the hydrolyzed collagen peptides from vertebrates [62].

\section{Antiviral activity}

Anemonia viridis contain large number of polypeptide toxins, such as blood-depressing substances (BDS) peptides. These are 43 amino acid peptides characterized by three disulfide bonds that act as neurotoxins affecting Kv3.1, Kv3.2 and Kv3.4 channel gating kinetics. In addition, BDS-1 inactivates the Nav1.7 and Nav1.3 channels and show anti-viral effects [63] (fig. 3).

\section{Anti-inflammatory activity}

Two Kunitz-type inhibitors isolated from Sea anemones Heteractis crispa RG (HCRG) polypeptide subfamily have been isolated from the sea anemone Heteractis crispa. HCRG1 and HCRG2 possess antiinflammatory activity, reducing tumor necrosis factor- $\alpha$ (TNF- $\alpha$ ) and interleukin 6 (IL-6) secretions, as well as proIL-1 $\beta$ expression in lipopolysaccharide (LPS)-activated macrophages [64]. Sea anemone Heteractis crispa contain Kunitz-type peptides, which have potassium channels blocking activity. This peptide reduced the synthesis of TNF- $\alpha$, a pro-inflammatory mediator playing a leading role in the development of edema in this model [65]. Sea anemone Metridiumsenile contain peptide toxinsTXMs 9a-1. The transient receptor potential ankyrin-repeat 1 (TRPA1) is an important player in pain and inflammatory pathways. It shows antiinflammatory effects in experimental mice. Sea anemone Heteractis crispa Kunitz-type peptides showed anti-inflammatory and antihistamine effects [66]. Ueq 12-1 is a unique peptide potentiator of the TRPA1 receptor that produces anti-inflammatory effects in vivo. Sea anemone Urticina eques contain a bioactive peptide named $\alpha$ AnmTxUeq 12-1. It consists of 45 amino acids including 10 cysteine residues (fig. 3).

\section{Anti-helminthic activity}

Nematostellavectensis encoding the putative nematocyst venom proteins: a metallopeptidase related to the Tolloid family and a cysteine-rich protein. These show anti-helmintic activity AnewKunitz-type protease inhibitor InhVJ from the sea anemone Heteractis crispa (Radianthus macrodactylus). The significant role of Glu45 for the orientation and stabilization of the InhVJ-trypsin complex was elucidated. P1 Thr residue instead of Lys might lead to refinement of inhibitor specificity in the direction of subfamilies of serine proteases. The absence of Kv channel and TRPV1-receptor modulation activity was confirmed by electrophysiological screening tests [67]. Sea anemone Anthopleura dowii Verrill contain venom, including proteases, neurotoxins that could act as either potassium $(\mathrm{K}+)$ or sodium $(\mathrm{Na}+)$ channels inhibitors, protease inhibitors, phospholipases A2, and other polypeptides [68]. Venomous animals from distinct phyla such as spiders, scorpions, snakes, cone snails, or sea anemones produce small toxic proteins interacting with a variety of cell targets. Their bites often cause pain [68]. One of the ways of pain generation is the activation of TRPV1 channels [70]. Sea anemone Bunodactisverrucosa contain putative toxins including metalloproteinases and neurotoxins which is responsible for basal metabolism and biosynthesis of antibiotics [71] (fig. 3).

\section{Analgesic effect}

Cnidarians have been known since ancient times for the painful stings they induce to humans. The effects of the stings range from skin irritation to cardiotoxicity and can result in the death of human beings [72]. The venom of sea anemone Metridium senile contain 35-amino acid peptidet-AnmTXMs 9a-1 (short name Ms 9a-1) Ms 9a-1 potentiates the response of TRPA1 to endogenous agonists followed by persistent functional loss of TRPA1-expressing neurons. TRPA1 potentiating may be useful as a therapeutic approach as Ms 9a-1 produces significant analgesic and anti-inflammatory effects in mice models of pain. A new multigene HCIQ subfamily from the sea anemone Heteractis crispa contain Kunitz-peptides shows neuroprotective activity against 6-hydroxydopamine [73]. Sea anemone Heteractis crispa venoms have Kunitz-type peptides so named "analgesic cluster" of the HCGS peptide subfamily but forms a separate branch on the NJ-phylogenetic tree. rHCRG21 is the first full peptide TRPV1 inhibitor, although displaying a lower affinity for its receptor in comparison with other known ligands. rHCRG21-TRPV1 complex allow hypothesizing the existence of two feasible, intra-and extracellular, molecular mechanisms of blocking. These data provide valuable insights in the structural and functional relationships and pharmacological potential of bifunctional Kunitz-type peptides [74].

\section{Anti-diabetic activity}

Sea Anemone Heteractis magnifica mucus, contain Magnificamide, a $\beta$-Defensin-Like Peptidetargets, mainly on cytoplasmic membranes and ion channels. It is a rich source of pancreatic $\alpha$-amylase inhibitors, which maintain the glucose level in the blood and can be used for the treatment of prediabetes and type 2 diabetes mellitus. The main function of magnificamide is the inhibition of $\alpha$-amylases act as potential drug candidate for the treatment of type 2 diabetes mellitus [75] (fig. 3).

\section{Immunomodulating activity}

Sea anemone Stichodactyla helianthus, CCR7-effector memory T (TEM) lymphocytes. These cells express Kv1.3 potassium channels that play a major role in their activation. These act as potential immunomodulators for the treatment of autoimmune diseases. Stichodactyla helianthus is a potent blocker of Kv1.3. ShK-186, a synthetic analog of ShK, is therapeutic for autoimmune diseases [76] (fig. 3).

\section{Mode of action}

Cniderians toxins peptides acts on ligand-gated ion channels, including acid-sensing ion channel (ASIC) toxins. Thistoxins breaks glycerophospholipids, which produces lysophospholipid and fatty acids, such as the arachidonic acid. The metabolites derived from arachidonic acid (prostaglandins, thromboxanes and leukotrienes) control a variety of cellular functions, including dietary lipid catabolism, in cell membrane metabolism and inflammatory diseases. It include a large variety of proteinase enzymes, which host a metal atom to perform their catalytic activity. These toxins mainly acts on Voltage-Gated Sodium and Potassium Channel Toxins. Voltage-gated ion channels activate non-selective pores within membranes by which the ions can pass using the electrochemical gradient across the membrane itself. When this mechanism is altered, the transmission of signals through the neurons and muscles is critically changed too, which can lead to certain disorders, including paralysis. These toxins, whose molecular mass ranges from 3.5 to $6.5 \mathrm{kDa}$, are able to bind specifically with the receptor site three of the sodium channel, and regulate their functioning. By controlling the opening and closing of the sodium channel, the toxins control the electrical signals that encode and propagate vital information across long distances. The activity of the sodium channel toxins shows these toxins act as pain blockers. Heteractiscrispa contain Sodium channel inhibitors which was not suitable for pharmacological applications but useful to study the mechanisms of these sodium and potassium channel toxins transportation and thus to produce insecticides. Bunodosomacaissarum BcsTx1 and BcsTx2 secreted by sea anemone type 1 potassium channel toxins interact with voltage-gated K+channels (KV) mainly rKv1.2 over rKv1.6, hKv1.3, Shaker IR and rKv1.1 (Cnidaria, Anthozoa). Sea anemones Heteractiscrispa contain peptide toxins APETx-2. It also contain wo APETx-like peptides, Hcr 1b-2 and Hcr 1b-4 which interfaces with the rASIC1a channel [77]. The nematocysts of the sea anemone Actinia bermudensis contain peptide toxinsAbeTx1that possess a ring of basic amino acids that shows multipoint interaction for the binding of the toxin to the channel Sea anemone Anthopleura dowii Verrillvenom, contain proteases, neurotoxins, phospholipases $\mathrm{A} 2$, and other polypeptides, that act as either potassium $\left(\mathrm{K}^{+}\right)$or sodium $\left(\mathrm{Na}^{+}\right)$channels inhibitors [78]. 


\section{Toxin bio-prospecting}

Cnidarians possess an articulated cocktail of bioactive substances. 88Sea anemone-like Anemonia viridis contains peptide toxins arsenal is a major pool of neurotoxins. These act upon sodium and potassium channels [79]. If its RNA-Sequences and regulatory gene could be explored, than its expression effect can be measured by using simulation modeling.

Moreover, A. viridis toxins can be used for biotechnological applications for generation of new drugs of various biological and therapeutic activity. Similarly, Hydra magnipapillata and Nematostella vectensis belong to a prominent family cnidarians possess $\alpha$-crystallin gene that could be used for biotechnological purposes [80]. The scyphomedusa Rhizostomapulmo is an outbreak-forming jellyfish act as vectors of bacterial pathogens [81]. Various coelenterate species possess unique mixture of toxin peptides with diverse biological and pharmacological activities [56, 82]. These toxins also act as defense molecules used by various coelenterate species [83].

\section{CONCLUSION}

Most of the coelenterates secrete venom that is a diverse arsenal of peptides and proteins used in self-defense and to immobilize the prey. These low molecular weight toxin peptides interact to voltagegated sodium and potassium channels. These toxins fire membranes and form and accelerate active passage of ions which pass using the electrochemical gradient across the membrane itself. Coelenterate toxins show diverse biological activity such as anti-angiogenesis effects and cytolytic activity against human myelogenous leukemia and cancer cell lines. These pore-forming toxins show action much similar to actinoporins and cause hemolysis. Sea anemone $B$. verrucosa contain metalloproteinases and neurotoxins. These also show Kunitz-type protease inhibitor and pancreatic $\alpha$-amylase inhibitor activity. These also show anti-pathogenic effects against microbes such as viruses, bacteria, protozoan and fungal species. These show anti-helminthic activity, analgesic effect, anti-diabetic activity and immunomodulating activity are of great of pharmacological and biotechnological interest. These could be used for the generation of new highly effective drug molecules for the treatment of various human diseases. These toxins could be used as a natural source for the development of alternative medicine.

\section{ACKNOWLEDGEMENT}

I thank HOD department of Zoology, Deen Dayal Upadhyaya Gorakhpur University, Gorakhpur for facilities.

\section{FUNDING}

Nil

\section{AUTHORS CONTRIBUTIONS}

All the authors have contributed equally.

\section{CONFLICTS OF INTERESTS}

Declared none

\section{REFERENCES}

1. Zhang Y. Why do we study animal toxins? Dongwuxue Yanjiu. 2015;36(4):183-222. doi: 10.13918/j.issn.20958137.2015.4.183, PMID 26228472.

2. Frazao B, Vasconcelos V, Antunes A. Sea anemone (Cnidaria, Anthozoa, Actiniaria) toxins: an overview. Mar Drugs. 2012;10(8):1812-51. doi: 10.3390/md10081812, PMID 23015776.

3. Rocha J, Peixe L, Gomes NC, Calado R. Cnidarians as a source of new marine bioactive compounds- an overview of the last decade and future steps for bioprospecting. Mar Drugs. 2011;9(10):1860-86. doi: 10.3390/md9101860, PMID 22073000.

4. Hoepner CM, Abbott CA, Burke da Silva K. The ecological importance of toxicity: sea anemones maintain toxic defence when bleached. Toxins (Basel). 2019;11(5):266. doi: 10.3390/toxins11050266, PMID 31083576.
5. Moran Y, Praher D, Schlesinger A, Ayalon A, Tal Y, Technau U. Analysis of soluble protein contents from the nematocysts of a model sea anemone sheds light on venom evolution. Mar Biotechnol (NY). 2013;15(3):329-39. doi: 10.1007/s10126012-9491-y, PMID 23151943.

6. Jouiaei M, Yanagihara AA, Madio B, Nevalainen TJ, Alewood PF, Fry BG. Ancient venom systems: a review on Cnidaria toxins. Toxins (Basel). 2015;7(6):2251-71. doi: 10.3390/toxins7062251, PMID 26094698.

7. Nevalainen MT, Valve EM, Ingleton PM, Nurmi M, Martikainen PM, Harkonen PL. Prolactin and prolactin receptors are expressed and functioning in the human prostate.J Clin Invest. 1997;99(4):618-27. doi: 10.1172/JCI119204, PMID 9045863.

8. Mariottini GL, Pane L. Cytotoxic and cytolytic cnidarian venoms. A review on health implications and possible therapeutic applications. Toxins (Basel). 2013;6(1):108-51. doi: 10.3390/toxins6010108, PMID 24379089.

9. Moore RE, Scheuer PJ. Palytoxin: a new marine toxin from a coelenterate. Science. 1971;172(3982):495-8. doi: 10.1126/science.172.3982.495, PMID 4396320.

10. D'Ambra I, Lauritano C. A review of toxins from Cnidaria. Mar Drugs. 2020;18(10):507. doi: 10.3390/md18100507, PMID 33036158.

11. Klompen AML, Macrander J, Reitzel AM, Stampar SN. Transcriptomic analysis of four cerianthid (Cnidaria, Ceriantharia) venoms. Mar Drugs. 2020;18(8):413. doi: 10.3390/md18080413, PMID 32764303

12. Madio B, King GF, Undheim EAB. Sea anemone toxins: A structural overview. Mar Drugs. 2019;17(6):325. doi: 10.3390/md17060325, PMID 31159357.

13. Honma T, Shiomi K. Peptide toxins in sea anemones: structural and functional aspects. Mar Biotechnol (NY). 2006;8(1):1-10. doi: 10.1007/s10126-005-5093-2, PMID 16372161.

14. Madio B, Peigneur S, Chin YKY, Hamilton BR, Henriques ST, Smith JJ, Cristofori-Armstrong B, Dekan Z, Boughton BA, Alewood PF, Tytgat J, King GF, Undheim EAB. PHAB toxins: a unique family of predatory sea anemone toxins evolving via intra-gene concerted evolution defines a new peptide fold. Cell Mol Life Sci. 2018;75(24):4511-24. doi: 10.1007/s00018-0182897-6, PMID 30109357.

15. Dominguez Perez D, Campos A, Alexei Rodriguez A, Turkina MV, Ribeiro T, Osorio H, Vasconcelos V, Antunes A. Proteomic analyses of the unexplored sea anemone Bunodactis verrucosa. Mar Drugs. 2018;16(2):42. doi: 10.3390/md16020042, PMID 29364843.

16. Ramirez Carreto S, Vera Estrella R, Portillo Bobadilla T, Licea Navarro A, Bernaldez Sarabia J, Rudino Pinera E, Verleyen JJ, Rodriguez E, Rodriguez Almazan C. Transcriptomic and proteomic analysis of the tentacles and mucus of Anthopleuradowii Verrill, 1869. Mar Drugs. 2019;17(8):436. doi: $10.3390 / \mathrm{md} 17080436$, PMID 31349621.

17. Yamaguchi Y, Hasegawa Y, Honma T, Nagashima Y, Shiomi K. Screening and cDNA cloning of Kv1 potassium channel toxins in sea anemones. Mar Drugs. 2010;8(12):2893-905. doi: 10.3390/md8122893, PMID 21339955.

18. Orts B DJ, Peigneur S, Silva Gonçalves LC, Arcisio Miranda M, PW Bicudo JEJ. AbeTx1 Is a novel sea anemone toxin with a dual mechanism of action on shaker-type $\mathrm{K}^{+}$channels activation. Mar Drugs. 2018;16:360.

19. Wanke E, Zaharenko AJ, Redaelli E, Schiavon E. Actions of sea anemone type 1 neurotoxins on voltage-gated sodium channel isoforms. Toxicon. 2009;54(8):1102-11. doi: 10.1016/j.toxicon.2009.04.018, PMID 19393679.

20. Honma T, Minagawa S, Nagai H, Ishida M, Nagashima Y, Shiomi K. Novel peptide toxins from acrorhagi, aggressive organs of the sea anemone Actinia equina. Toxicon. 2005;46(7):768-74. doi: 10.1016/j.toxicon.2005.08.003, PMID 16183092.

21. Kalina RS, Koshelev SG, Zelepuga EA, Kim NY, Kozlov SA, Kozlovskaya EP, Monastyrnaya MM, Gladkikh IN. APETx-like peptides from the sea anemone Heteractis crispa, diverse in their effect on ASIC1a and ASIC3 ion channels. Toxins (Basel). 2020;12(4):266. doi: 10.3390/toxins12040266, PMID 32326130 . 
22. Kim $\mathrm{CH}$, Lee YJ, Go HJ, Oh HY, Lee TK, Park JB, Park NG. Defensin-neurotoxin dyad in a basally branching metazoan sea anemone. FEBS Journal. 2017;284(19):3320-38. doi: 10.1111/febs.14194, PMID 28796463.

23. Prentis PJ, Pavasovic A, Norton RS. Sea anemones: quiet achievers in the field of peptide toxins. Toxins (Basel). 2018;10(1):36. doi: 10.3390/toxins10010036, PMID 29316700.

24. Li R, Yu H, Li T, Li P. Comprehensive proteome reveals the key lethal toxins in the venom of jellyfish Nemopile manomurai. J Proteome Res. 2020;19(6):2491-500. doi: 10.1021/ acs.jproteome.0c00277, PMID 32374608.

25. Ovchinnikova TV, Balandin SV, Aleshina GM, Tagaev AA, Leonova YF, Krasnodembsky ED, Men'shenin AV, Kokryakov VN. Aurelin, a novel antimicrobial peptide from jellyfish Aurelia aurita with structural features of defensins and channelblocking toxins. Biochem Biophys Res Commun 2006;348(2):514-23. doi: 10.1016/j.bbrc.2006.07.078, PMID 16890198.

26. Li R, Yu H, Xue W, Yue Y, Liu S, Xing R, Li P. Jellyfish venomics and venom gland transcriptomics analysis of Stomolo phusmeleagris to reveal the toxins associated with sting. J Proteomics. 2014;106:17-29. doi: 10.1016/j.jprot.2014.04.011, PMID 24747124.

27. Li A, Yu H, Li R, Liu S, Xing R, Li P. Inhibitory effect of metalloproteinase inhibitors on skin cell inflammation induced by jellyfish Nemopile manomurai nematocyst venom. Toxins (Basel). 2019;11(3):156. doi: 10.3390/toxins11030156, PMID 30857352.

28. Huang C, Morlighem JR, Zhou H, Lima ÉP, Gomes PB, Cai J, Lou I, Perez CD, Lee SM, Radis Baptista G. The transcriptome of the zoanthid Protopalythoa variabilis (Cnidaria, Anthozoa) predicts a basal repertoire of toxin-like and venom-auxiliary polypeptides. Genome Biol Evol. 2016;8(9):3045-64. doi: 10.1093/gbe/evw204, PMID 27566758.

29. Rathje K, Mortzfeld B, Hoeppner MP, Taubenheim J, Bosch TCG, Klimovich A. Dynamic interactions within the host-associated microbiota cause tumor formation in the basal metazoan Hydra. PLOS Pathog. 2020;16(3):e1008375. doi: 10.1371/journal.ppat.1008375, PMID 32191776

30. Yan L, Fei K, Zhang J, Dexter S, Sarras MP Jr. Identification and characterization of hydra metalloproteinase 2 (HMP2): a meprin-like astacin metalloproteinase that functions in foot morphogenesis. Development. 2000;127(1):129-41. doi: 10.1242/dev.127.1.129, PMID 10654607.

31. Pierobon P, Parmeggiani A, von Oppen F, Frey E. Dynamic correlation functions and Boltzmann-Langevin approach for driven one-dimensional lattice gas. Phys Rev E Stat Nonlin Soft Matter Phys. 2005;72(3 Pt 2):036123:036123. doi: 10.1103/PhysRevE.72.036123.

32. Ben-Ari H, Paz M, Sher D. The chemical armament of reefbuilding corals: inter-and intra-specific variation and the identification of an unusual actinoporin in Stylophora pistilata. Sci Rep 2018;8:251.

33. Grimme likhuijzen CJ. Coexistence of neuropeptides in hydra. Neuroscience. 1983;9(4):837-45. doi: 10.1016/03064522(83)90272-5, PMID 6353276.

34. Milbradt AG, Boulegue C, Moroder L, Renner C. The two cysteine-rich head domains of minicollagen from Hydra nematocysts differ in their cystine framework and overall fold despite an identical cysteine sequence pattern. J Mol Biol. 2005;354(3):591-600. doi: 10.1016/j.jmb.2005.09.080, PMID 16257007.

35. Jiemy WF, Hiew LF, Sha HX, In LLA, Hwang JS. Evaluation of hydra HALT-1 as a toxin moiety for recombinant immunotoxin. BMC Biotechnol. 2020;20(1):31. doi: 10.1186/s12896-020-00628-9, PMID 32552895

36. Beeton C, Pennington MW, Wulff $H$, Singh $S$, Nugent $D$, Crossley G, Khaytin I, Calabresi PA, Chen CY, Gutman GA, Chandy KG. Targeting effector memory $\mathrm{T}$ cells with a selective peptide inhibitor of Kv1.3 channels for therapy of autoimmune diseases. Mol Pharmacol. 2005;67(4):1369-81. doi: 10.1124/ mol.104.008193, PMID 15665253.
37. Sachkova MY, Landau M, Surm JM, Macrander J, Singer SA, Reitzel AM, Moran Y. Toxin-like neuropeptides in the sea anemone Nematostella unravel recruitment from the nervous system to venom. Proc Natl Acad Sci USA. 2020;117(44):27481-44927481-92. 10.1073/pnas.2011120117, PMID 33060291.

38. Liao Q, Gong G, Siu SWI, Wong CTT, Yu H, Tse YC, Radis Baptista G, Lee SM. A novel ShK-like toxic peptide from the transcriptome of the cnidarian Palythoacaribaeorum displays neuroprotection and cardioprotection in zebrafish. Toxins (Basel). 2018;10(6):238. doi: 10.3390/toxins10060238, PMID 29895785.

39. Chagot B, Escoubas P, Diochot S, Bernard C, Lazdunski M, Darbon H. Solution structure of APETx2, a specific peptide inhibitor of ASIC3 proton-gated channels. Protein Sci. 2005;14(8):2003-10. doi: 10.1110/ps.051378905, PMID 15987885.

40. Nicosia A, Mikov A, Cammarata M, Colombo P, Andreev Y, Kozlov S, Cuttitta A. The anemoniaviridis venom: coupling biochemical purification and RNA-seq for translational research. Mar Drugs. 2018 Oct 25;16(11):407. doi: 10.3390/md16110407, PMID 30366463

41. Orts DJ, Peigneur S, Madio B, Cassoli JS, Montandon GG, Pimenta AM, Bicudo JE, Freitas JC, Zaharenko AJ, Tytgat J. Biochemical and electrophysiological characterization of two sea anemone type 1 potassium toxins from a geographically distant population of Bunodosoma caissarum. Mar Drugs. 2013;11(3):655-79. doi: 10.3390/md11030655, PMID 23466933.

42. Dominguez Perez D, Rodriguez AA, Osorio H, Azevedo J, Castaneda O, Vasconcelos V, Antunes A. MicrocystinLR detected in a low molecular weight fraction from a crude ext ract of Zoanthus sociatus. Toxins (Basel). 2017;9(3):89. doi: $10.3390 /$ toxins 9030089

43. Zhang R, Jin L, Zhang N, Petridis AK, Eckert T, Scheiner Bobis G, Bergmann M, Scheidig A, Schauer R, Yan M, Wijesundera SA, Norden B, Chatterjee BK, Siebert HC. The sialic acid-dependent nematocyst discharge process in relation to its physicalchemical properties is a role model for nanomedical diagnostic and therapeutic tools. Mar Drugs. 2019;17(8):469. doi: 10.3390/md17080469, PMID 31409009.

44. Rivera-de-Torre E, Palacios Ortega J, Slotte JP, Gavilanes JG Martinez Del-Pozo A, Garcia Linares S. Functional and structural variation among sticholysins, pore-forming proteins from the Sea Anemone Stichodactyla helianthus. Int J Mol Sci. 2020;21(23):8915. doi: 10.3390/ijms21238915, PMID 33255441 .

45. Liew YJ, Soh WT, Jiemy WF, Hwang JS. Mutagenesis and functional analysis of the pore-forming toxin HALT-1 from Hydra magnipapillata. Toxins (Basel). 2015;7(2):407-22. doi: 10.3390/toxins7020407, PMID 25654788.

46. Stabili L, Schirosi R, Parisi MG, Piraino S, Cammarata M. The mucus of actinia equina (Anthozoa, Cnidaria): an unexplored resource for potential applicative purposes. Mar Drugs. 2015;13(8):5276-96. doi: 10.3390/md13085276, PMID 26295400 .

47. Leychenko E, Isaeva $\mathrm{M}$, Tkacheva $\mathrm{E}$, Zelepuga E, Kvetkina $\mathrm{A}$, Guzev K, Monastyrnaya M, Kozlovskaya E. Multigene family of pore-forming toxins from sea anemone Heteractis crispa. Mar Drugs. 2018;16(6):183. doi: 10.3390/md16060183, PMID 29794988.

48. Tejuca M, Anderluh G, Macek P, Marcet R, Torres D, Sarracent J, Alvarez C, Lanio ME, Dalla Serra M, Menestrina G. Antiparasite activity of sea-anemone cytolysins on Giardia duodenalis and specific targeting with anti-Giardia antibodies. Int J Parasitol. 1999;29(3):489-98. doi: 10.1016/s0020-7519(98)00220-3, PMID 10333333

49. Liang X, Wang R, Dou W, Zhao L, Zhou L, Zhu J, Wang K, Yan J. Arminin 1a-C, a novel antimicrobial peptide from ancient metazoan Hydra, shows potent antileukemia activity against drug-sensitive and drug-resistant leukemia cells. Drug Des Devel Ther. 2018;12:3691-703. doi: 10.2147/DDDT.S181188, PMID 30464401. 
50. Sintsova O, Gladkikh I, Kalinovskii A, Zelepuga E, Monastyrnaya M, Kim N, Shevchenko L, Peigneur S, Tytgat J, Kozlovskaya E, Leychenko E. Magnificamide, a $\beta$-defensin-like peptide from the mucus of the sea anemone Heteractis magnifica, is a strong inhibitor of mammalian $\alpha$-amylases. Mar Drugs. 2019;17(10):542. doi: 10.3390/md17100542, PMID 31546678.

51. Osmakov DI, Kozlov SA, Andreev YA, Koshelev SG, Sanamyan NP, Sanamyan KE, Dyachenko IA, Bondarenko DA, Murashev AN, Mineev KS, Arseniev AS, Grishin EV. Sea anemone peptide with uncommon $\beta$-hairpin structure inhibits acid-sensing ion channel 3 (ASIC3) and reveals analgesic activity. J Biol Chem. 2013;288(32):23116-27. doi: 10.1074/jbc.M113.485516, PMID 23801332.

52. Andreev YA, Osmakov DI, Koshelev SG, Maleeva EE, Logashina YA, Palikov VA. Analgesic activity of acid-sensing. Ion Channels 3 (ASIC3) Inhibitors: Sea Anemones Peptides Ugr9-1 and APETx2 versus low molecular weight compounds. Mar Drugs. 2012;16:500.

53. Babenko VV, Mikov AN, Manuvera VA, Anikanov NA, Kovalchuk SI, Andreev YA, Logashina YA, Kornilov DA, Manolov AI, Sanamyan NP, Sanamyan KE, Kostryukova ES, Kozlov SA, Grishin EV, Govorun VM, Lazarev VN. Identification of unusual peptides with new Cys frameworks in the venom of the coldwater sea anemone Cnidopus japonicus. Sci Rep. 2017;7(1):14534. doi: 10.1038/s41598-017-14961-1, PMID 29109403.

54. Mariottini GL, Pane L. Mediterranean jellyfish venoms: a review on sScyphomedusae. Mar Drugs. 2010;8(4):1122-52. doi: 10.3390/md8041122, PMID 20479971.

55. Alvarez C, Ros U, Valle A, Pedrera L, Soto C, Hervis YP, Cabezas S, Valiente PA, Pazos F, Lanio ME. Biophysical and biochemical strategies to understand membrane binding and pore formation by sticholysins, pore-forming proteins from a sea anemone. Biophys Rev. 2017;9(5):529-44. doi: 10.1007/s12551-017-0316-0, PMID 28853034.

56. Bulati M, Longo A, Masullo T, Vlah S, Bennici C, Bonura A, Salamone M, Tagliavia M, Nicosia A, Mazzola S, Colombo P, Cuttitta A. Partially purified extracts of sea anemone nemonia viridis affect the growth and viability of selected tumour cell lines. BiomMed Res Int. 2016:3849897;2016:3849897. doi: 10.1155/2016/3849897.

57. Ayed Y, Sghaier RM, Laouini D, Bacha H. Evaluation of antiproliferative and anti-inflammatory activities of Pelagianoctiluca venom in lipopolysaccharide/interferon- $\gamma$ stimulated RAW264.7 macrophages. Biomed Pharmacother. 2016;84:1986-91. doi: 10.1016/j.biopha.2016.11.010, PMID 27876211.

58. Loret EP, Luis J, Nuccio C, Villard C, Mansuelle P, Lebrun R, Villard P. A low molecular weight protein from the sea anemone Anemonia viridis with anti-angiogenic activity. Mar Drugs. 2018;16(4):134. doi: 10.3390/md16040134.

59. Dominguez Perez D, Campos A, Alexei Rodriguez A, Turkina MV, Ribeiro T, Osorio H, Vasconcelos V, Antunes A. Proteomic analyses of the unexplored sea anemone bunodactis verrucosa. Mar Drugs. 2018;16(2):42. doi: 10.3390/md16020042, PMID 29364843.

60. D'Ambra, Chiara Lauritano. A review of toxins from Cnidaria I. Mar Drugs. 2020;1:18, 507.
61. Kalina RS, Peigneur S, Zelepuga EA, Dmitrenok PS, Kvetkina AN, Kim NY, Leychenko EV, Tytgat J, Kozlovskaya EP, Monastyrnaya MM, Gladkikh IN. New insights into the Type II toxins from the sea anemone Heteractis crispa. Toxins. 2020;12(1):44. doi: 10.3390/toxins12010044, PMID 31936885

62. Monastyrnaya M, Peigneur S, Zelepuga E, Sintsova O, Gladkikh I, Leychenko E, Isaeva M, Tytgat J, Kozlovskaya E. Kunitz type peptide HCRG21 from the sea anemone Heteractis crispa Iis a full antagonist of the TRPV1 receptor. Mar Drugs. 2016;14(12):229. doi: 10.3390/md14120229, PMID 27983679.

63. Sintsova O, Gladkikh I, Kalinovskii A, Zelepuga E, Monastyrnaya M, Kim N, Shevchenko L, Peigneur S, Tytgat J, Kozlovskaya E, Leychenko E. Magnificamide, a $\beta$-defensin-like peptide from the mucus of the sea anemone Heteractis magnifica, is a strong inhibitor of mammalian $\alpha$-amylases. Mar Drugs. 2019;17(10):542. doi: 10.3390/md17100542, PMID 31546678.

64. Chi V, Pennington MW, Norton RS, Tarcha EJ, Londono LM, Sims-Fahey B, Upadhyay SK, Lakey JT, Iadonato S, Wulff $\mathrm{H}_{\text {, }}$ Beeton C, Chandy KG. Development of a sea anemone toxin as an immunomodulator for therapy of autoimmune diseases. Toxicon. 2012 Mar 15;59(4):529-46. doi: 10.1016/j.toxicon.2011.07.016, PMID 21867724.

65. Kalina RS, Koshelev SG, Zelepuga EA, Kim NY, Kozlov SA, Kozlovskaya EP, Monastyrnaya MM, Gladkikh IN. APETx-like peptides from the sea anemone heteractis crispa, diverse in their effect on ASIC1a and ASIC3 Iion channels. Toxins (Basel). 2020;12(4):266. doi: 10.3390/toxins12040266, PMID 32326130 .

66. Ramirez Carreto S, Vera-Estrella R, Portillo-Bobadilla T, LiceaNavarro A, Bernaldez-Sarabia J, Rudino-Pinera E, Verleyen JJ, Rodriguez E, Rodriguez-Almazan C. Transcriptomic and proteomic analysis of the tentacles and mucus of anthopleura dowii verrill, 1869. Mar Drugs. 2019;17(8):436. doi: $10.3390 / \mathrm{md} 17080436$

67. Nicosia A, Maggio T, Mazzola S, Cuttitta A. Evidence of accelerated evolution and ectodermal-specific expression of presumptive BDS toxin cDNAs from Anemonia viridis. Mar Drugs. 2013;11(11):4213-31. doi: 10.3390/md11114213, PMID 24177670.

68. Nicosia A, Maggio T, Mazzola S, Gianguzza F, Cuttitta A, Costa S. Characterization of small HSPs from Anemoniaviridis reveals insights into the molecular evolution of alpha-crystallin genes among cnidarians. PLoS One. 2014;9(9):e105908. doi: 10.1371/journal.pone.0105908, PMID 25251681.

69. Stabili L, Rizzo L, Basso L, Marzano M, Fosso B, Pesole G, Piraino S. The microbial community associated with rhizostoma pulmo: Eecological significance and potential consequences for marine organisms and human health. Mar Drugs. 2020;18(9):437. doi: 10.3390/md18090437, PMID 32839397.

70. Kumar RB, Suresh MX. Neurotox: a unique database for animal neurotoxins. Int J Pharm Pharm Sci. 2015;7:351-4.

71. Asawale KY, MC Mehta MC, PS. Uike PS. Drug utilization analysis of anti-snake venom at a tertiary care center in central maharashtra: a 3 y retrospective study. Asian J Pharm Clin Res. 2018;11(8):134-7. doi: 10.22159/ajpcr.2018.v11i8.26174. 